\title{
Prevalence of Helicobacter pylori among children in a training and research hospital clinic in Istanbul and comparison with Updated Sydney Classification Criteria
}

\author{
(i) Begum Calim Gurbuz, ${ }^{1}$ (i) Hande Nur Inceman, ${ }^{1}$ (i) Merve Aydemir, ${ }^{1}$ (i) Coskun Celtik, ${ }^{2}$ \\ (D) Nelgin Gerenli, ${ }^{2}$ (D) Ebru Zemheri ${ }^{1}$ \\ ${ }^{1}$ Department of Pathology, Istanbul Health Sciences University Umraniye Training and Research Hospital, Istanbul, Turkey \\ 2Department of Pediatric Gastroenterology, Istanbul Health Sciences University Umraniye Training and Research Hospital, Istanbul, Turkey
}

\begin{abstract}
OBJECTIVE: Helicobacter pylori $(H$. pylori) is a gram-negative bacterium and one of the reasons for gastritis, peptic and duodenal ulcers. It is a crucial public health problem for both children and adults, especially in developing countries. This study aims to investigate the prevalence of Helicobacter pylori positivity in children and to compare with updated Sydney classification criteria.

METHODS: This study was conducted from January 2015 to June 2017. This study included 885 children aged 0-17 year(s). Endoscopic biopsies were evaluated for the diagnosis of infection due to $H$. pylori.

RESULTS: The findings showed that 418 (47.2\%) of 885 children were positive for $H$. pylori, and this positivity had a significantly increasing correlation with the presence of chronic inflammation, neutrophilic activity, lymphoid aggregates, and follicles. Erythematous pangastritis and antral nodularity on endoscopic findings had a correlation with $H$. pylori positivity.

CONCLUSION: In this hospital-based study, the findings suggest that $H$. pylori infection is a problem for children and more extensive studies are needed to determine the prevalence of $H$. pylori positivity among children.

Keywords: H. pylori among children; Sydney classification.

Cite this article as: Calim Gurbuz B, Inceman HN, Aydemir M, Celtik C, Gerenli N, Zemheri E. Prevalence of Helicobacter pylori among children in a training and research hospital clinic in Istanbul and comparison with Updated Sydney Classification Criteria. North Clin Istanb 2020;7(5):499-505.
\end{abstract}

Telicobacter pylori is a gram-negative microLorganism that is commonly seen worldwide. Robin Warren and Barry Marshall discovered it as the causative agent of gastritis and peptic ulcer in 1982 [1]. More than $50 \%$ of the world's population is infected with $H$. pylori [2]. It is also more common in develop-

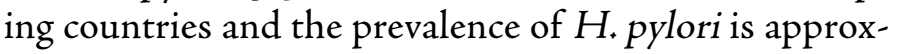
imately $90 \%$ in these countries [3].

H. pylori-associated infection can be either clinically silent or non-specific. Specific signs or symptoms are including esophagitis, gastroesophageal reflux, and various motility disorders. Older children with peptic complaints may have symptoms more than younger children,

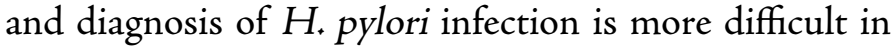
early childhood. Childhood, early adult years, living in developing or poor countries have an apparent risk for infection [4].

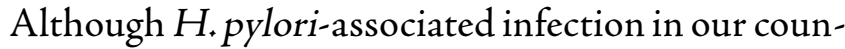
try has limited data for the epidemiology, in Turkey, the prevalence of $H$. pylori infection in children has been

Received: May 09, 2019 Accepted: February 06, 2020 Online: August 17, 2020

Correspondence: Begum CALIM GURBUZ, MD. Istanbul Saglik Bilimleri Universitesi, Umraniye Egitim ve Arastirma Hastanesi, Patoloji Klinigi, Istanbul, Turkey.

Tel: +90 2129096000 - 20102 e-mail: begumcalim@hotmail.com

(c) Copyright 2020 by Istanbul Provincial Directorate of Health - Available online at www.northclinist.com 
reported as different rates, from $23.6 \%$ to $78.5 \%$ [4, $5]$. Therefore, this study was conducted to evaluate the prevalence of $H$. pylori in children in Western Turkey and also to investigate the association between $H_{\text {. }}$ pylori, updated Sydney classification criteria and endoscopic findings.

\section{MATERIALS AND METHODS}

In total, 885 children's endoscopic biopsies, which were taken from the Department of Pediatric Gastroenterology, from January 2015 to June 2017, were evaluated for endoscopic and histologic findings. According to endoscopic findings and preliminary diagnosis, the patients clarified to erythematous pangastritis, antral nodularity, erosion/ulcer on gastric mucosa, esophagitis, celiac disease, duodenitis, and inflammatory bowel disease. One patient may have more than one endoscopic findings and preliminary diagnosis.

Patients who were less than 18 years old were included in our study. The patients were divided into four groups considering their age. Group 1 included patients who were $0-5$ year(s), Group 2 included patients who were 6-10 years, Group 3 included patients who were 11-15 years, and Group 4 included patients who were $16-17$ years.

The biopsies were placed on the filter paper, fixed in $10 \%$ neutral buffered formalin, and embedded in paraffin. Serial sections of $5 \mu \mathrm{m}$ were prepared for each fragment and stained with hematoxylin-eosin, modified Giemsa for evaluating $H_{\text {. }}$ pylori, and periodic acid Schiff and alcian blue (PAS-AB) for evaluating intestinal metaplasia. Histomorphological evaluation was performed according to the Updated Sydney System criteria [6]. $H$. pylori positivity, chronic inflammation and neutrophilic activity were reported as none (0), mild (1), moderate (2) and severe (3). Lymphoid aggregates, lymphoid follicles, intestinal metaplasia and atrophy were defined as absent (0) or present (1).

Ethical clearance for this study was provided by the Medical Ethics Committee of Health Sciences University with B.10.1.TKH.4.34.H.GP.0.01/195 number on 23 October 2019.

\section{Statistical Methods}

IBM SPSS Statistics 22 was used for the statistical anal$y$ sis. The suitability of the parameters to the normal distribution was evaluated by the Shapiro Wilks test for less
TABLE 1. Findings of the total patients

Demographic features

$\%$

Sex

Female $\quad 58.3$

Male

41.7

Age groups

0-5 year(s) (Group 1) 11.6

6-10 years (Group 2) 22.2

$11-15$ years (Group 3) $\quad 44.4$

16-17 years (Group 4) $\quad 21.8$

Endoscopic findings

Erythematous pangastritis $\quad 74.8$

Antral nodularity $\quad 15.1$

Erosion and ulcer on gastric mucosa $\quad 2.1$

Preliminary diagnosis

Celiac $\quad 6.4$

Esophagitis $\quad 6.2$

Duodenitis $\quad 3.2$

Inflammatory bowel disease $\quad 0.8$

H. pylori

Negative $\quad 52.8$

Positive

47.2

than 50 samples and Konglomorov test for more than 50 samples. Descriptive statistical methods (mean, standard deviation, frequency) were used as well as the Chi-square test, Fisher Freeman Halton test, and Continuity (Yates) Correction for comparison of qualitative data. Significance was evaluated as $\mathrm{p}<0.05$.

\section{RESULTS}

According to the demographic evaluation of the patients who underwent endoscopic biopsy, there were 885 children-516 females (58.3\%) and 369 males (41.7\%). The most crowded group was Group 3, with 393 children (44.4\%) aged 11-15 years. Erythematous pangastritis was the most common endoscopic finding with 662 children (74.8\%). 418 of 885 patients was positive for $H$. pylori (47.2\%) (Table 1).

Females were $60.3 \%$, and males were $39.7 \%$ of $H$. pylori-positive group. 11-15 years old, group 3, had the highest rate $(46.4 \%)$ of all $H$. pylori positive age groups. Erythematous pangastritis (82\%) was the most common endoscopic finding in the patients who were H. pylori in- 
fected. The grading of $H$. pylori positivity was $50.2 \%$ for mild infection, $30.9 \%$ for moderate infection, $18.9 \%$ for severe infection. Histologically, moderate neutrophilic activity (40.7\%) and moderate chronic inflammation

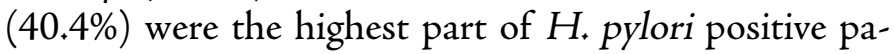
tients. Lymphoid aggregates were found as $77.5 \%$ and lymphoid follicles were found as $45.4 \%$ in $H_{\text {. pylori-pos- }}$ itive patients (Table 2).

According to Updated Sydney Classification Sys-

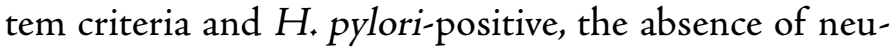
trophilic activity and chronic inflammation were found statistically more significant in $H$. pylori negative patients $(68.3 \%, 7.1 \%)$ than the absence of neutrophilic activity and chronic inflammation in mild $H_{\text {. pylori-pos- }}$ itive patients $(24.3 \%, 0.9 \%)(\mathrm{p}=0.001 ; \mathrm{p}<0.05)$. In mild H. pylori-positive patients, mild neutrophilic activity was $55.2 \%$ and mild chronic inflammation was $71.9 \%$. These rates were $18.1 \%$ for moderate neutrophilic activity, $22.4 \%$ for moderate chronic inflammation, $2.4 \%$ for severe neutrophilic activity, and $4.8 \%$ for severe chronic inflammation. Mild neutrophilic activity and chronic inflammation were found statistically significant compared to moderate and severe neutrophilic activity and chronic inflammation in mild $H$. pylori-positive patients $(p=0.001 ; p<0.05)$. In addition, there was a statistically significant difference between the severity of H. pylori and the presence of lymphoid aggregates and follicles. As a result of binary comparisons made for the determination of difference, the presence of lymphoid aggregates was statistically lower in $H$. pylori negative patients $(52.5 \%)$ compared to mild $(68.1 \%)$, moderate $(83.7 \%)$ and severe $(92.4 \%) H$. pylori-positive patients $(\mathrm{p}=0.001 ; \mathrm{p}<0.05)$. Same way, the presence of lymphoid follicles was statistically lower in $H$. pylori negative patients $(10.3 \%)$ compared to mild (26.2\%), moderate $(60.5 \%)$ and severe $(72.2 \%) H$. pylori-positive patients $(p=0.001 ; p<0.05)$. The rate of the presence of lymphoid aggregates and follicles in moderate $H$. pyloripositive children $(83.7 \%, 60.5 \%)$ and in severe $H_{*}$ pylori positive children $(92.4 \%, 72.2 \%)$ also had a higher incidence than mild $H$. pylori positive children $(68.1 \%$, $26.2 \%)(p=0.001 ; p<0.05)$. Intestinal metaplasia and atrophy was $0.5 \%$ in the total patient group. There was no statistically significant difference between $H$. pylori, atrophy, and intestinal metaplasia ( $p>0.05)$ (Table 3 ).

Different endoscopic findings and preliminary diagnosis were existing in $H$. pylori-positive patients. The rate of erythematous pangastritis was statistically lower in $H$. pylori negative patients $(68.3 \%)$ compared to mild
TABLE 2. Findings of the $H$. pylori-positive patient

\begin{tabular}{|c|c|}
\hline Demographic features & $\%$ \\
\hline \multicolumn{2}{|l|}{ Sex } \\
\hline Female & 60.3 \\
\hline Male & 39.7 \\
\hline \multicolumn{2}{|l|}{ Age groups } \\
\hline 0-5 year(s) (Group 1) & 6.7 \\
\hline $6-10$ years (Group 2 ) & 20.6 \\
\hline $11-15$ years (Group 3 ) & 46.4 \\
\hline 16-17 years (Group 4) & 26.3 \\
\hline \multicolumn{2}{|l|}{ Endoscopic findings } \\
\hline Erythematous pangastritis & 82 \\
\hline Antral nodularity & 26.5 \\
\hline Erosion and ulcer on gastric mucosa & 2.1 \\
\hline \multicolumn{2}{|l|}{ Preliminary diagnosis } \\
\hline Esophagitis & 5.2 \\
\hline Celiac & 5.02 \\
\hline Duodenitis & 3.3 \\
\hline Inflammatory bowel disease & 1.1 \\
\hline \multicolumn{2}{|l|}{ H. pylori grading } \\
\hline Mild & 50.2 \\
\hline Moderate & 30.9 \\
\hline Severe & 18.9 \\
\hline None & 12.4 \\
\hline \multicolumn{2}{|l|}{ Neutrophilic activity } \\
\hline Mild & 30.4 \\
\hline Moderate & 40.7 \\
\hline Severe & 16.5 \\
\hline None & 0.5 \\
\hline \multicolumn{2}{|l|}{ Chronic inflammation } \\
\hline Mild & 39 \\
\hline Moderate & 40.4 \\
\hline Severe & 20.1 \\
\hline \multicolumn{2}{|l|}{ Lymphoid aggregates } \\
\hline Absent & 22.5 \\
\hline Present & 77.5 \\
\hline \multicolumn{2}{|l|}{ Lymphoid follicles } \\
\hline Absent & 54.6 \\
\hline Present & 45.4 \\
\hline
\end{tabular}

(76.2\%), moderate (89.1\%) and severe (86.1\%) H. pyloripositive patients $(p=0.037, p=0.001, p=0.002 ; p<0.05$, respectively). The rate of antral nodularity was statistically higher in mild (12.4\%), moderate (37.2\%) and severe (46.8\%) H. pylori-positive patients compared to $H_{\text {. pylori }}$ negative patients $(4.9 \%)(\mathrm{p}=0.001 ; \mathrm{p}<0.05)$ (Table 4). 
TABLE 3. Grading of $H$. pylori positivity and the Updated Sydney System criteria comparison

\begin{tabular}{|c|c|c|c|c|c|c|c|c|c|c|c|}
\hline & \multicolumn{8}{|c|}{ Helicobacter pylori } & \multicolumn{2}{|c|}{ Total } & \multirow[t]{3}{*}{$\mathrm{p}$} \\
\hline & \multicolumn{2}{|c|}{ None } & \multicolumn{2}{|c|}{ Mild } & \multicolumn{2}{|c|}{ Moderate } & \multicolumn{2}{|c|}{ Severe } & \multirow[b]{2}{*}{$\mathrm{n}$} & \multirow[b]{2}{*}{$\%$} & \\
\hline & $\mathrm{n}$ & $\%$ & $\mathrm{n}$ & $\%$ & $\mathrm{n}$ & $\%$ & $\mathrm{n}$ & $\%$ & & & \\
\hline \multicolumn{12}{|c|}{ Neutrophilic activity } \\
\hline None & 319 & 68.3 & 51 & 24.3 & 1 & 0.8 & 0 & 0 & 371 & 41.9 & \multirow{4}{*}{$0.001^{1}$} \\
\hline Mild & 136 & 29.1 & 116 & 55.2 & 11 & 8.5 & 0 & 0 & 263 & 29.7 & \\
\hline Moderate & 8 & 1.7 & 38 & 18.1 & 97 & 75.2 & 35 & 44.3 & 178 & 20.1 & \\
\hline Severe & 4 & 0.9 & 5 & 2.4 & 20 & 15.5 & 44 & 55.7 & 73 & 8.3 & \\
\hline \multicolumn{12}{|c|}{ Chronic inflammation } \\
\hline None & 33 & 7.1 & 2 & 0.9 & 0 & 0 & 0 & 0 & 35 & 4 & \multirow{4}{*}{$0.001^{1}$} \\
\hline Mild & 400 & 85.7 & 151 & 71.9 & 8 & 6.2 & 4 & 5.1 & 563 & 63.6 & \\
\hline Moderate & 30 & 6.4 & 47 & 22.4 & 94 & 72.9 & 28 & 35.4 & 199 & 22.5 & \\
\hline Severe & 4 & 0.8 & 10 & 4.8 & 27 & 20.9 & 47 & 59.5 & 88 & 9.9 & \\
\hline \multicolumn{12}{|c|}{ Lymphoid aggregates } \\
\hline Absent & 222 & 47.5 & 67 & 31.9 & 21 & 16.3 & 6 & 7.6 & 316 & 35.7 & \multirow{2}{*}{$0.001^{2}$} \\
\hline Present & 245 & 52.5 & 143 & 68.1 & 108 & 83.7 & 73 & 92.4 & 569 & 64.3 & \\
\hline \multicolumn{12}{|c|}{ Lymphoid follicle } \\
\hline Absent & 419 & 89.7 & 155 & 73.8 & 51 & 39.5 & 22 & 27.8 & 647 & 73.1 & \multirow{2}{*}{$0.001^{2}$} \\
\hline Present & 48 & 10.3 & 55 & 26.2 & 78 & 60.5 & 57 & 72.2 & 238 & 26.9 & \\
\hline \multicolumn{12}{|l|}{ Atrophy } \\
\hline Absent & 465 & 99.6 & 209 & 99.5 & 129 & 100 & 78 & 98.7 & 881 & 99.5 & \multirow{2}{*}{$0.488^{1}$} \\
\hline Present & 2 & 0.4 & 1 & 0.5 & 0 & 0 & 1 & 1.3 & 4 & 0.5 & \\
\hline \multicolumn{12}{|c|}{ Intestinal metaplasia } \\
\hline Absent & 478 & 99.8 & 202 & 96.2 & 126 & 97.7 & 75 & 94.9 & 881 & 99.5 & \multirow{2}{*}{$0.503^{1}$} \\
\hline Present & 2 & 0.4 & 1 & 0.5 & 0 & 0 & 1 & 1.3 & 4 & 0.5 & \\
\hline
\end{tabular}

1: Fisher Freeman Halton Test; 2: Chi-square Test; *: $p<0.05$.

\section{DISCUSSION}

H. pylori is the most common chronic bacterial infection in developing countries [7]. The prevalence of the disease is $90 \%$ in developing countries and higher than the developed countries (40\%), except in Japan [6,8]. Generally,

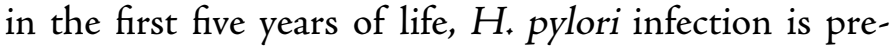
sented more than half of the world's population $[9,10]$. The proportion of $H$. pylori infection during adulthood is over $90 \%$ in developing countries, whereas the H. pylori infection rate is from $30 \%$ to $50 \%$ of children in the same countries [11]. The prevalence of the infection is low (1.2-12.2\%) in children of developed countries [12].

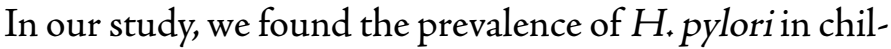
dren as $47.2 \%$, similar to developing countries.

The prevalence of $H$. pylori infection may differ from developing countries to other developing countries.
Highest prevalence belongs to Bangladeshi children $(80 \%)$ and after Indian children (57\%) $[13,14]$. Prevalence of H. pylori in Turkey is different in many studies. Ozden et al. [5] evaluated the patients aged between $7-14$ years in 1990 and 2000 separately by serological tests. They found the prevalence of $H$. pylori infection as $78.5 \%$ in 1990 , and as $66.3 \%$ in 2000 . The conclusion was

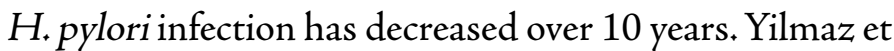
al. [15] found the seropositivity of $H$. pylori as $43.9 \%$ of 346 children, and Selimoglu et al. [16] reported the

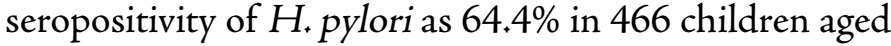
6-17 years in eastern Turkey. These findings suggest that the results can be different even in the same country.

In eastern Turkey, the prevalence of $H$. pylori is found $30.7 \%$ with culture, $66.3 \%$ with PCR and $63.2 \%$ with a histological examination in children from ages 4 to 18 
TABLE 4. Grading of $H$. pylori positivity and endoscopic findings/preliminary diagnosis comparison

\begin{tabular}{|c|c|c|c|c|c|c|c|c|c|c|c|}
\hline & \multicolumn{8}{|c|}{ Helicobacter pylori } & \multirow{2}{*}{\multicolumn{2}{|c|}{ Total }} & $\mathrm{p}$ \\
\hline & \multicolumn{2}{|c|}{ None } & \multicolumn{2}{|c|}{ Mild } & \multicolumn{2}{|c|}{ Moderate } & \multicolumn{2}{|c|}{ Severe } & & & \\
\hline & $\mathrm{n}$ & $\%$ & $\mathrm{n}$ & $\%$ & $\mathrm{n}$ & $\%$ & $\mathrm{n}$ & $\%$ & $\mathrm{n}$ & $\%$ & \\
\hline \multicolumn{12}{|l|}{ Endoscopic findings } \\
\hline Erythematous pangastritis & 319 & 68.3 & 160 & 76.2 & 115 & 89.1 & 68 & 86.1 & 662 & 74.8 & $\mathbf{0 . 0 0 1} 1^{1}$ \\
\hline Antral nodularity & 23 & 4.9 & 26 & 12.4 & 48 & 37.2 & 37 & 46.8 & 134 & 15.1 & $0.001^{1}$ \\
\hline Erosion/ulcer on gastric mucosa & 10 & 2.1 & 5 & 2.4 & 2 & 1.6 & 2 & 2.5 & 19 & 2.1 & $0.955^{2}$ \\
\hline \multicolumn{12}{|l|}{ Preliminary diagnosis } \\
\hline Celiac & 36 & 7.7 & 15 & 7.1 & 3 & 2.3 & 3 & 3.8 & 57 & 6.4 & $0.114^{2}$ \\
\hline Esophagitis & 33 & 7.1 & 13 & 6.2 & 3 & 2.3 & 6 & 7.6 & 55 & 6.2 & $0.248^{2}$ \\
\hline Duodenitis & 14 & 3 & 4 & 1.9 & 7 & 5.5 & 3 & 3.8 & 28 & 3.2 & $0.328^{2}$ \\
\hline Inflammatory bowel disease & 2 & 0.4 & 2 & 1 & 3 & 2.3 & 0 & 0 & 7 & 0.8 & $0.148^{2}$ \\
\hline
\end{tabular}

1: Chi-square Test; 2: Fisher Freeman Halton Test; *: $p<0.05$.

years From March 2011 to September 2012 by Ozbey et al. [17]. In that study, patients 13 to 18 years old show the highest prevalence $(75.8 \%)$, while 4 to 6 years old have the lowest prevalence (40\%). In our study, H. pylori was presented in all age groups, but children aged 11-15 years, had the highest rate.

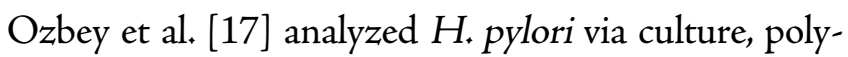
merase chain reaction and histopathological diagnosis in 101 children in 2015. They observed antral nodularity in 55 children $(54.5 \%)$ of which $76.4 \%$ were $H$. pyloripositive. Relationship between $H$. pylori and endoscopic nodular gastritis was shown by Bahu et al. also [18]. 27\% of their patients was positive for $H$. Pylori, and 22 of 50 children, $44 \%$ of all patients, had antral nodularity. Their rate of antral nodularity in $H$. pylori positive patients was lower compared to the rate of Dogan et al. [19] (73.6\% antral nodularity), and Ozcay et al. [20] (64.7\% antral nodularity). Association of $H_{\text {. }}$ pylori and antral nodularity was higher, as $98.5 \%$ in a Japanese study [21]. Peptic ulcer prevalence differs in children from country to country between $1.8 \%$ and $19.5 \%$ [20, 22]. The prevalence of peptic ulcer was 8.6\% in European children in 2005 and 13.2\% in Turkish children in 2011 [23, 24]. In our study, we observed that erythematous pangastritis and antral nodularity were the most common endoscopic findings, and the relation with $H$. pylori infection was statistically significant.

Two techniques for detecting $H$. pylori infection can be used. These techniques are grouped as noninvasive and invasive tests. They are microbiological culture, rapid urease test (RUT), histological test and polymerase chain reaction (PCR). For histological examination, esophagogastroduodenoscopy (EGD) and biopsies are necessary $[7,25]$. Histological testing has an advantage of evaluating pathologic changes, such as the severity of chronic inflammation, the grade of atrophy, intestinal metaplasia, and malignancy [26, 27]. However, we should keep in mind that using some medications, such as proton pump inhibitors (PPIs), antibiotics and bismuth, may decrease the sensitivity and specificity of the histological test [26]. Cohen et al. [28] studied 79 gastric biopsies from pediatric patients. Thirty-five biopsies were mild for neutrophilic infiltration, and 38 biopsies were mild for mononuclear infiltrates. Langner et al. evaluated 132 biopsies from symptomatic children infected

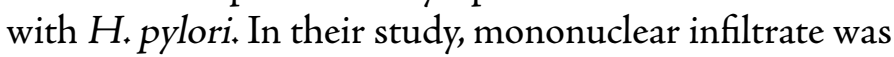
observed in $98.5 \%$, and polymorphonuclear cell infiltrate was observed in $93.9 \%$ of the biopsies $[29,30]$. Lymphoid aggregates were observed $13.6 \%$ and lymphoid follicles were observed $31.8 \%$ of the patients in the study

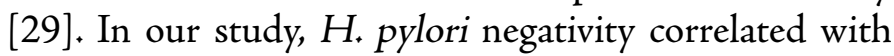
the absence of neutrophilic activity and chronic inflam-

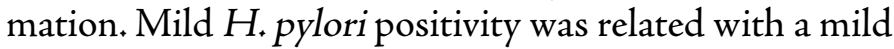
degree of neutrophilic activity and chronic inflammation as well. Lymphoid aggregates and lymphoid follicles were

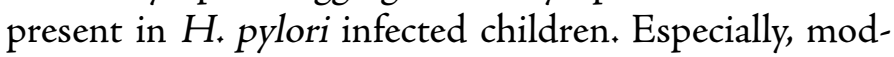
erate and severe $H$. pylori infection correlated with the presence of lymphoid aggregates and lymphoid follicles. 
The ratio of gastric atrophy and intestinal metaplasia influences from geography/genetics and environmental factors [17]. In one study, intestinal metaplasia was found

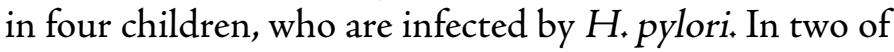
them, atrophy was present [30]. In one Japanese study, $4.6 \%$ of children had both intestinal metaplasia and $H$. pylori positivity [31]. The proportion of gastric atrophy was high in Columbian children (16\%) and also higher in Japanese children $(51.9 \%)$ [31, 32]. In our study, there was no correlation between intestinal metaplasia, atrophy, and $H$. pylori.

In conclusion, it can be seen that the studies conducted concerning $H$. pylori for pediatric patients in Turkey are generally from eastern regions, while mid- and western regions have relatively little research for the topic. Since this paper is western-based, it can be said that it will be an important contribution to the literature. Besides that, in completed research where serological tests are widely used, to our knowledge, there is no Turkish research that evaluates $H$. Pylori positivity with histopathological evidences to our knowledge. Based on this, this study can be seen as an initial step that will lead to further investigations. During our research, we found that the results of

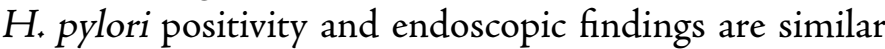
to the ratios in the mid- and eastern regions of Turkey. When the results are compared to worldwide studies, similarities to developing countries have been noticed. In addition, it is also observed that early detection of $H$. pylori infection among children is important and may reduce the complications later in life.

Ethics Committee Approval: The Umraniye Training and Research Hospital Clinical Research Ethics Committee granted approval for this study (date: 23.10.2019, number: 205).

Conflict of Interest: No conflict of interest was declared by the authors.

Financial Disclosure: The authors declared that this study has received no financial support.

Authorship Contributions: Concept - BCG, HNI, MA, CC, NG, EZ; Design - BCG, HNI, MA, CC, NG, EZ; Supervision - BCG, HNI, MA, CC, NG, EZ; Materials - BCG, HNI, MA, CC, NG; Data collection and/ or processing - BCG, CC, NG; Analysis and/or interpretation - BCG, HNI, MA; Literature review - BCG, EZ; Writing - BCG, EZ; Critical review - BCG, EZ.

\section{REFERENCES}

1. Marshall BJ, Warren JR. Unidentified curved bacilli in the stomach of patients with gastritis and peptic ulceration. Lancet 1984;1:1311-5.

2. Ansari S, Gautam R, Nepal HP, Subedi SN, Shrestha S, Mandal F, et al. Helicobacter pylori colonization in Nepal; assessment of prevalence and potential risk factors in a hospital-based patient cohort. BMC Res Notes 2016;9:59. [CrossRef]

3. Abdul Rahim NR, Benson J, Grocke K, Vather D, Zimmerman J, Moody T, et al. Prevalence of Helicobacter pylori infection in newly arrived refugees attending the Migrant Health Service, South Australia. Helicobacter 2017;22. [CrossRef]

4. Ceylan A, Kirimi E, Tuncer O, Türkdoğan K, Ariyuca S, Ceylan N. Prevalence of Helicobacter pylori in children and their family members in a district in Turkey. J Health Popul Nutr 2007;25:422-7.

5. Ozden A, Bozdayi G, Ozkan M, Köse KS. Changes in the seroepidemiological pattern of Helicobacter pylori infection over the last 10 years. Turk J Gastroenterol 2004; 15(3):156-8.

6. Tonkic A, Tonkic M, Lehours P, Mégraud F. Epidemiology and diagnosis of Helicobacter pylori infection. Helicobacter 2012;17 Suppl 1:1-8.

7. Guarner J, Kalach N, Elitsur Y, Koletzko S. Helicobacter pylori diagnostic tests in children: review of the literature from 1999 to 2009. Eur J Pediatr 2010;169:15-25. [CrossRef]

8. Garza-González E, Perez-Perez GI, Maldonado-Garza HJ, BosquesPadilla FJ. A review of Helicobacter pylori diagnosis, treatment, and methods to detect eradication. World J Gastroenterol. 2014;20:1438-49.

9. Rajindrajith S, Devanarayana NM, de Silva HJ. Helicobacter pylori infection in children. Saudi J Gastroenterol 2009;15:86-94. [CrossRef]

10. Suerbaum S, Michetti P. Helicobacter pylori infection. N Engl J Med 2002;347:1175-86. [CrossRef]

11. Salih BA. Helicobacter pylori infection in developing countries: the burden for how long?. Saudi J Gastroenterol 2009;15:201-7. [CrossRef]

12. Mourad-Baars PE, Verspaget HW, Mertens BJ, Mearin ML. Low prevalence of Helicobacter pylori infection in young children in the Netherlands. Eur J Gastroenterol Hepatol 2007;19:213-6. [CrossRef]

13. Ahmad MM, Ahmed DS, Rowshon AH, Dhar SC, Rahman M, Hasan $\mathrm{M}$, et al. Long-term re-infection rate after Helicobacter pylori eradication in Bangladeshi adults. Digestion 2007;75:173-6. [CrossRef]

14. Mishra S, Singh V, Rao GR, Dixit VK, Gulati AK, Nath G. Prevalence of Helicobacter pylori in asymptomatic subjects--a nested PCR based study. Infect Genet Evol 2008;8:815-9. [CrossRef]

15. Yilmaz E, Doğan Y, Gürgöze MK, Unal S. Seroprevalence of Helicobacter pylori infection among children and their parents in eastern Turkey. J Paediatr Child Health 2002;38:183-6. [CrossRef]

16. Selimoglu MA, Ertekin V, Inandi T. Seroepidemiology of Helicobacter pylori infection in children living in eastern Turkey. Pediatr Int 2002;44:666-9. [CrossRef]

17. Ozbey G, Dogan Y, Demiroren K, Ozercan IH. Prevalence of Helicobacter pylori in children in eastern Turkey and molecular typing of isolates. Braz J Microbiol 2015;46:505-11. [CrossRef]

18. Bahú Mda G, da Silveira TR, Maguilnick I, Ulbrich-Kulczynski J. Endoscopic nodular gastritis: an endoscopic indicator of high-grade bacterial colonization and severe gastritis in children with Helicobacter pylori. J Pediatr Gastroenterol Nutr 2003;36:217-22. [CrossRef]

19. Dogan Y, Baris S, Erkan T, Önal Z, Usta M, Çullu Çokuğraş F, et al. Helicobacter pylori infection in children: Evaluation of complaints, endoscopic findings, diagnostic methods and post-treatment eradication rates. Turk Arch Ped 2007;42:98-102.

20. Ozçay F, Koçak N, Temizel IN, Demir H, Ozen H, Yüce A, et al. Helicobacter pylori infection in Turkish children: comparison of diagnostic tests, evaluation of eradication rate, and changes in symptoms after eradication. Helicobacter 2004;9:242-8. [CrossRef]

21. Kato S, Nishino Y, Ozawa K, Konno M, Maisawa S, Toyoda S, et al. The prevalence of Helicobacter pylori in Japanese children with gastritis 
or peptic ulcer disease. J Gastroenterol 2004;39:734-8. [CrossRef]

22. Elitsur Y, Lawrence Z. Non-Helicobacter pylori related duodenal ulcer disease in children. Helicobacter 2001;6:239-43. [CrossRef]

23. Mégraud F; European Paediatric Task Force on Helicobacter pylori. Comparison of non-invasive tests to detect Helicobacter pylori infection in children and adolescents: results of a multicenter European study. J Pediatr 2005;146:198-203. [CrossRef]

24. Uğraş M, Pehlivanoğlu E. Helicobacter pylori infection and peptic ulcer in eastern Turkish children: is it more common than known? Turk J Pediatr 2011;53:632-7.

25. Ou Z, Xiong L, Li DY, Geng L, Li L, Chen P, Yang M, Zeng Y, Zhou $\mathrm{Z}$, Xia H, Gong S. Evaluation of a new fluorescence quantitative PCR test for diagnosing Helicobacter pylori infection in children. BMC Gastroenterol. 2013 Jan 14;13:7. [CrossRef]

26. Kanna MS, Romereo CM, Fas R. Diagnostic tests for Helicobacter pylori. Gastroenterol Endosc News 2013;11:51-8.

27. Malfertheiner P, Megraud F, O'Morain CA, Atherton J, Axon AT, Bazzoli F, et al; European Helicobacter Study Group. Management of Helicobacter pylori infection--the Maastricht IV/ Florence Consensus
Report. Gut 2012;61:646-64. [CrossRef]

28. Cohen MC, Cueto Rúa E, Balcarce N, Donatone J, Drut R. Assessment of the Sydney System in Helicobacter pylori-associated gastritis in children. Acta Gastroenterol Latinoam 2000;30:35-40.

29. Langner M, Machado RS, Patrício FR, Kawakami E. Evaluation of gastric histology in children and adolescents with Helicobacter pylori gastritis using the Update Sydney System. Arq Gastroenterol 2009;46:328-32. [CrossRef]

30. Guarner J, Bartlett J, Whistler T, Pierce-Smith D, Owens M, Kreh R, et al. Can pre-neoplastic lesions be detected in gastric biopsies of children with Helicobacter pylori infection? J Pediatr Gastroenterol Nutr 2003;37:309-14. [CrossRef]

31. Kato S, Nakajima S, Nishino Y, Ozawa K, Minoura T, Konno M, et al. Association between gastric atrophy and Helicobacter pylori infection in Japanese children: a retrospective multicenter study. Dig Dis Sci 2006;51:99-104. [CrossRef]

32. Ricuarte O, Gutierrez O, Cardona H, Kim JG, Graham DY, El-Zimaity HM. Atrophic gastritis in young children and adolescents. J Clin Pathol 2005;58:1189-93. [CrossRef] 